\title{
Siddha Based Decoctions Better Remedy to Overcome COVID-19 - A Review
}

\author{
IJCRR \\ Section: Healthcare \\ Sci. Journal Impact \\ Factor: 6.1 (2018) \\ ICV: 90.90 (2018) \\ (c) (i) (8) \\ Copyright@IJCRR
}

\section{Swetha $\mathbf{R}^{1}$, Dinesh Premavathy ${ }^{2}$}

'Saveetha Dental College and Hospitals, Saveetha Institute of Medical and Technical Sciences, Saveetha University, Chennai-77, India; ${ }^{2}$ Senior Lecturer, Saveetha Dental College and Hospitals, Saveetha Institute of Medical and Technical Sciences, Saveetha University, Chennai-77, India.

\section{ABSTRACT}

Background: The novel Coronavirus disease 2019 (COVID-19) is caused by SARS-CoV-2, which is the causative agent of a potentially deadly disease that is of severe global public health concern. The rapid onset of COVID-19 is wreaking havoc worldwide because of inadequate risk assessment regarding the urgency of the situation. The COVID-19 infection has spread over 210 countries and territories around the world as there are no clinically approved treatments or vaccines available to date. When compared with SARS and MERS, COVID-19 has spread drastically, due to increased globalization and adaptation of the virus in every environment. Siddha system of medicine (SSM) is one of the oldest traditional systems of medicine, which has originated from India and is practiced mainly in the southern part of this country for curing different types of diseases including even chronic conditions. Siddha based approaches have been proved to cure various respiratory diseases.

Material and Method: The present study has reviewed articles through various internet sources such as PubMed, Science Direct, and Google Scholar.

Conclusion: The present study explores the properties of different traditional herbs in treating the novel Coronavirus disease. The aim of the study is to analyze Siddha-based decoctions as a better remedy in overcoming COVID-19. The present study has collected various articles related to the current topic from multiple internet sources. The present study thus concluded that the Siddha-based decoctions may mitigate the COVID-19.

Key Words: Herbs, Siddha medicine, Coronavirus, SARS-CoV-2, Kabasura Kudineer, Nilavembu Kudineer

\section{INTRODUCTION}

Human coronaviruses belong to the order Nidovirales, family Coronaviridae, and genus Alphacoronavirus or Betacoronavirus ${ }^{1}$. The emerging SARS-CoV-2, a beta coronavirus, can cause COVID-19, is highly contagious; respiratory droplets and contact are the main routes of transmission ${ }^{2}$. The SARS-CoV-2 infection, exhibited by clustering onset, is more likely to affect elderly people with comorbidities and pregnant women ${ }^{3}$. It is common that for people who are in contact with a large number of viruses or whose immune functions are compromised, they have a greater chance to be infected than others. The estimated mean incubation period of SARS-CoV-2 is 1-14 days ${ }^{4}$. Fever is generally the major and basic symptom of COVID-19, which can be followed by no symptom or other symptoms such as dry cough, shortness of breath, muscle ache, dizziness, headache, sore throat, rhinorrhea, chest pain, diarrhea, nausea, and vomiting 5 . In severe cases, patients rapidly continued to develop the acute respiratory syndrome, septic shock, metabolic acidosis, and coagulopathy ${ }^{6}$.

The Siddha system of medicine is one of among the earliest branches of the traditional Indian medical system and can be traced back to the Sangam period (500 BC) ${ }^{7}$. This system of medicine follows the holistic approach of healthcare ${ }^{8,9}$. According to the Siddha literature, the vitiation of environmental factors such as water, air, place, and season are regarded to be responsible for the formation of diseases. When contamination and vitiation of these components occur, epidemics follow ${ }^{10}$. At present water-borne diseases, environmental diseases, epidemiological disorders and seasonal disorders due to infections can be associated with Janapadodhwamsa Vyadhis, a medical term well defined in the Indian tradition-

\section{Corresponding Author:}

Dr. Dinesh Premavathy M.Sc., Ph.D, Senior Lecturer, Saveetha Dental College and Hospital, Saveetha Institute of Medical and Technical Sciences, Saveetha University, No. 162, Poonamallee High Road, Velappanchavadi, Chennai - 600077, Tamil Nadu, India; Mobile: +91 7010860212; Email: dineshp.sdc@saveetha.com

ISSN: 2231-2196 (Print)

Received: 22.08 .2020
ISSN: $0975-5241$ (Online)

Revised: 19.09 .2020
Accepted: 16.10 .2020
Published: 03.11.2020 
al medical system ${ }^{8}$. Several indigenous drugs have been illustrated in Siddha and Ayurveda for controlling inflammation, fever, and other diseases ${ }^{11,12,13,14}$. In the long term curing chronic disorders, like rheumatic diseases, combinations of different plant families, and species active principles usually exhibit remarkable potency and tolerance. Siddha based medicine may also aid in preserving the bone framework $15,16,17,18$. Traditional herbs can also promote proper internal regulation of the body 19,20

It is well recorded that the plant possessing anti-inflammatory properties also contain antipyretic and analgesic activities or vice versa. The nilavembu kudineer choornam (NKC) is a conventional preparation used in the treatment of chikungunya fever as Siddha medicine in Tamil Nadu, India. It is a mixture of commonly used food ingredients as well as medicinal plants ${ }^{21}$. Kabasura Kudineer is a compound concoction consisting of fifteen herbal ingredients. It is often used as a remedy for fever with or without respiratory infection. It was prescribed extensively during the epidemic of Swine flu as a prophylactic and media reports gave a renaissance to this official Siddha formulation ${ }^{22}$. Siddha medicinal preparations have been classified as 32 internal and 32 external medicinal forms and choornam is one among the internal medicinal form ${ }^{23}$.

The aim of the present study is to analyze Siddha-based remedy as a better approach to combat novel Coronavirus disease.

\section{MATERIALS AND METHODS}

The present study has collected various articles related to the current topic from various internet sources such as PubMed, ScienceDirect, Google Scholar.

\section{SIDDHA AND COVID-19}

\section{Siddha Medicine}

Siddha medicine is the ancient medical system that is broadly practiced in South India. It was enriched with ethnic medical knowledge of Tamil people, a native of the rich biodiversity zone of Western Ghats ${ }^{242526}$. A single herb may contain many phytochemical constituents that function alone or in combination with other compounds to produce the desired pharmacological effect ${ }^{27}$. The antiviral effects of medicinal plants have played a tremendous role at different stages of viral growth ${ }^{28}$. Plant-derived pharmacological formulations marked a major contribution to viral infections ${ }^{29}$. Based on the availability of suitable, efficient, and rapid bioassay systems, the antiviral compounds have been used for rapid screening from plant extracts and fractions ${ }^{30}$. Instead of synthetic antiviral drugs, medicinal plants deliver basic raw ma- terials for important antiviral drugs ${ }^{31}$. Synthetic drugs have been replaced by medicinal plants, as life-saving drugs in various viral diseases ${ }^{32}$.

\section{Contribution of Siddha medicine in the treatment of diseases}

Brahmananda bhairavam mathirai and Vishnu chakram are used for the treatment of the pyrexic phase of chikungunya and may perform as antivirals. Nilavembu Kudineer is recognized for its antipyretic, anti-inflammatory, and analgesic properties and hence has a role in immune modulation 33. Arumuga chenduram is a herb-metallic formulation acknowledged for its role in the recovery of fever and arthritis ${ }^{11}$. Linga Chenduram No. is one of the medicines used in Siddha for treating 'Azhal Keel Vayu' which may be associated with osteoarthritis having the symptoms of both pains and swelling in knee joints ${ }^{34}$. Thirikadugu choornam is used in the treatment of digestive disorders such as indigestion, dyspepsia, flatulence, and intermittent fever Development of Ayurvedic and Siddha Medicine via the Application of Modern Pharmaceutical Technique ${ }^{35}$. It is believed that the Siddha System of Medicine is effective in treating any type of disease $^{36}$. For example, it is effective in the treatment of skin diseases ${ }^{37}$, arthritis ${ }^{38}$. Siddha medical practitioners have also recorded that this system is very effective in reducing the highly debilitating conditions in HIV/AIDS ${ }^{39}$ as well as found to cure HIV positive and sexually transmitted diseases (STD) ${ }^{40}$. Siddha medicine can also be used to reduce hypertension ${ }^{41}$. Other diseases such as cancer and diabetes ${ }^{42}$ (literally known as putrunoi and neerizhivu noi in Siddha System of Medicine) can also be treated using Siddha drugs ${ }^{43}$.

\section{Role of Siddha medicine in COVID-19}

Nilavembu kudineer composition is equal to the heartwood of Santalum album Linn. (Santalaceae), rhizomes of Zingiber officinale Rosc. (Zingiberaceae), fruits of Piper nigrum Linn (Piperaceae), the whole plant of Andrographis paniculata (Burm) Wall. ex Nees (Acanthaceae), tubers of Cyperus rotundus Linn. (Cyperaceae), the roots of Vetiveria Zizanioides (Linn) Nash. (Poaceae), whole plant of Hedyotis corymbosa (Linn.) Lam. (Rubiaceae), root of Plectranthus Vettiveroides (Linn.) Nash. (Lamiaceae) and the entire plant of Trichosanthes cucumerina Linn. (Cucurbitaceae). All these plants are commonly used in the treatment of fever, inflammation, arthralgia, arthritis, gastric ulcer, jaundice and general debility conditions ${ }^{44}$.

In Siddha, Kabasura kudineer choornam is broadly prescribed for the control and prevention of swine flu. The phytochemical elements present in choornam may responsible for its anti-inflammatory, antipyretic, analgesic, anti-viral, anti-bacterial, anti-fungal, anti-oxidant, hepato-protective, anti-diabetic, anti-asthmatic, antitussive, immunomodulatory, antidiarrheal and anti-oxidant activities. ${ }^{45,46}$. 


\section{CONCLUSION}

The present study focused on limited Siddha-based medicinal herbs. In the future, further study has to be done using other traditional plants. Considering the anti-viral, anti-inflammatory properties of traditional herbs as well as absence of side effects of Siddha medicine, the present study thus concludes that Siddha-based decoctions are a better remedy to overcome COVID-19.

\section{ACKNOWLEDGEMENT}

The team extends our sincere gratitude to the Saveetha Dental College and Hospitals for their constant support and successful completion of this work.

\section{Conflict of Interest}

The authors declare no conflict of interest

\section{Source of Funding: Nil}

\section{REFERENCES}

1. Hong H, Wang Y, Chung H-T, Chen C-J. Clinical characteristics of novel coronavirus disease 2019 (COVID-19) in newborns, infants and children. Pediatr Neonatol. 2020 Apr;61(2):131-2.

2. Brüssow H. Faculty Opinions recommendation of Early Transmission Dynamics in Wuhan, China, of Novel Coronavirus-Infected Pneumonia [Internet]. Faculty Opinions - Post-Publication Peer Review of the Biomedical Literature. 2020.

3. Lal SK. Emerging Viral Diseases of Southeast Asia. Karger Medical and Scientific Publishers; 2007. 149 p.

4. Li Q, Guan X, Wu P, Wang X, Zhou L, Tong Y, et al. Early Transmission Dynamics in Wuhan, China, of Novel Coronavirus-Infected Pneumonia. N Engl J Med. 2020 Mar 26;382(13):1199207.

5. Etzioni A, Ochs HD. Primary Immunodeficiency Disorders: A Historic and Scientific Perspective. Academic Press; 2014. 376 p.

6. Chen N, Zhou M, Dong X, Qu J, Gong F, Han Y, et al. Epidemiological and clinical characteristics of 99 cases of 2019 novel coronavirus pneumonia in Wuhan, China: A descriptive study [Internet]. Vol. 395, The Lancet. 2020. p. 507-13.

7. Muniapan B, Rajantheran M. Ethics (business ethics) from the Thirukkural and its relevance for contemporary business leadership in the Indian context [Internet]. Vol. 4, International Journal of Indian Culture and Business Management. 2011. p. 453.

8. Subbarayappa BV. Siddha medicine: an overview [Internet]. Vol. 350, The Lancet. 1997. p. 1841-4.

9. Seppan P, Muhammed I, Mohanraj KG, Lakshmanan G, Premavathy D, Muthu SJ, et al. Therapeutic potential of Mucuna pruriens (Linn.) on ageing induced damage in dorsal nerve of the penis and its implication on erectile function: an experimental study using albino rats. Aging Male. 2018 Feb 15;1-14.

10. Jain J, Pai S, Sunil S. Standardization of in vitro assays to evaluate the activity of polyherbal siddha formulations against Chikungunya virus infection. Virusdisease. 2018 Mar;29(1):32-9.

11. Anbarasu K, Manisenthil KKT, Ramachandran S. Antipyretic, anti-inflammatory and analgesic properties of nilavembu kudineer choornam: a classical preparation used in the treatment of chikungunya fever [Internet]. Vol. 4, Asian Pacific Journal of Tropical Medicine. 2011. p. 819-23.

12. Krishna RN, Nivesh Krishna R, Yuvaraj Babu K. Estimation of stature from physiognomic facial length and morphological facial length [Internet]. Vol. 9, Research Journal of Pharmacy and Technology. 2016. p. 2071.

13. Nandhini JST, Thaslima Nandhini JS, Yuvaraj Babu K, Mohanraj KG. Size, Shape, Prominence and Localization of Gerdy's Tubercle in Dry Human Tibial Bones [Internet]. Vol. 11, Research Journal of Pharmacy and Technology. 2018. p. 3604.

14. Subashri A, Thenmozhi MS. Occipital Emissary Foramina in Human Adult Skull and Their Clinical Implications [Internet]. Vol. 9, Research Journal of Pharmacy and Technology. 2016. p. 716.

15. Keerthana B, Thenmozhi MS. Occurrence of foramen of huschke and its clinical significance [Internet]. Vol. 9, Research Journal of Pharmacy and Technology. 2016. p. 1835.

16. Pratha AA, Ashwatha Pratha A, Thenmozhi MS. A Study of Occurrence and Morphometric Analysis on Meningo Orbital Foramen [Internet]. Vol. 9, Research Journal of Pharmacy and Technology. 2016. p. 880.

17. Hafeez N, Thenmozhi. Accessory foramen in the middle cranial fossa [Internet]. Vol. 9, Research Journal of Pharmacy and Technology. 2016. p. 1880.

18. Choudhari S, Thenmozhi MS. Occurrence and Importance of Posterior Condylar Foramen [Internet]. Vol. 9, Research Journal of Pharmacy and Technology. 2016. p. 1083.

19. Menon A, Thenmozhi MS. Correlation between thyroid function and obesity [Internet]. Vol. 9, Research Journal of Pharmacy and Technology. 2016. p. 1568.

20. Samuel AR, Thenmozhi MS. Study of impaired vision due to Amblyopia [Internet]. Vol. 8, Research Journal of Pharmacy and Technology. 2015. p. 912.

21. Mitra SK, Gopumadhavan S, Rafiq M, Venkataranganna MV. Antihistaminic and antianaphylactic activity of HK-07, a herbal formulation [Internet]. Vol. 37, Indian Journal of Pharmacology. 2005. p. 300.

22. Ph.D BJ, JMphil B, scholar. Ph D., PSG College of arts and science, Coimbatore., MaheshwariM. Phil. V, et al. A Study on Plasma Treated Bamboo/Cotton Blended Fabric for Assessing Antibacterial Activity in Nano Encapsulated Textiles [Internet]. Vol. 5, International Journal of Advanced Research. 2017. p. 635-8. Available from: http://dx.doi.org/10.21474/ijar01/3858

23. K S, Sivaranjani K, Shakila R, Manickavasakam K. Standardization of Siddha Polyherbal Formulation Parangipattai Choornam [Internet]. Vol. 6, International Journal of Research in Ayurveda and Pharmacy. 2015. p. 443-8. Available from: http://dx.doi. org/10.7897/2277-4343.06485

24. Mahadevan H, Palraj V. Literature Review on Siddha Herbal Formulations (Kudineer) Available for The Management of Dengue [Internet]. Vol. 5, International Journal of Pharmacology and Clinical Sciences. 2016. p. 90-6.

25. Thejeswar EP, Thenmozhi MS. Educational Research-iPad System vs Textbook System [Internet]. Vol. 8, Research Journal of Pharmacy and Technology. 2015. p. 1158.

26. Sriram N, Thenmozhi, Yuvaraj S. Effects of Mobile Phone Radiation on Brain: A questionnaire based study [Internet]. Vol. 8, Research Journal of Pharmacy and Technology. 2015. p. 867.

27. Parasuraman S, Thing GS, Dhanaraj SA. Polyherbal formulation: Concept of ayurveda. Pharmacogn Rev. 2014 Jul;8(16):73-80.

28. Ranković B. Lichen Secondary Metabolites: Bioactive Properties and Pharmaceutical Potential. Springer; 2019. 260 p.

29. Cragg GM, Newman DJ, Snader KM. Natural Products in Drug Discovery and Development [Internet]. Vol. 60, Journal of Natural Products. 1997. p. 52-60. 
30. Scior T, Bender A, Tresadern G, Medina-Franco JL, MartínezMayorga K, Langer T, et al. Recognizing Pitfalls in Virtual Screening: A Critical Review [Internet]. Vol. 52, Journal of Chemical Information and Modeling. 2012. p. 867-81.

31. Moghadamtousi S, Nikzad S, Kadir H, Abubakar S, Zandi K. Potential Antiviral Agents from Marine Fungi: An Overview [Internet]. Vol. 13, Marine Drugs. 2015. p. 4520-38.

32. Gurib-Fakim A. Medicinal plants: Traditions of yesterday and drugs of tomorrow [Internet]. Vol. 27, Molecular Aspects of Medicine. 2006. p. 1-93.

33. Pal PP, Research Officer / Scientist -, Regional Research Institute for Homoeopathy, Tripura under Central Council for Research in Homoeopathy, Central Council for Research in Homoeopathy, New Delhi - Ministry of AYUSH, et al. Research Review of Genus Epidemicus [Internet]. Vol. 8, International Journal of Advanced Ayurveda, Yoga, Unani, Siddha and Homeopathy. 2019. p. 545-50.

34. Murugan R, Vembu T, Kumarswamy M. Toxicological Study of a Siddha Sastric Formulation Arumuga Chendhuram in Rat Model [Internet]. Journal of Applied Pharmaceutical Science. 2016. p. 081-7.

35. Devi DR, Ramya Devi D, Malarvizhi K, Abinaya M, Vedha Hari BN. Innovation of Natural Product as Suppository Base [Internet]. Vol. 26, Asian Journal of Chemistry. 2014. p. 3705-9.

36. Kannan R, Thenmozhi MS. Morphometric Study of Styloid Process and its Clinical Importance on Eagle's Syndrome [Internet]. Vol. 9, Research Journal of Pharmacy and Technology. 2016. p. 1137.

37. Thas JJ, Joseph Thas J. Siddha Medicine — background and principles and the application for skin diseases [Internet]. Vol. 26, Clinics in Dermatology. 2008. p. 62-78.

38. Lakshmi T, Krishnan V, Rajendran R, Madhusudhanan N. Azadirachta indica: A herbal panacea in dentistry - An update. Pharmacogn Rev. 2015 Jan;9(17):41-4.
39. Ravichandran S, Ramya SR, Kanungo R. Association of ABO blood groups with dengue fever and its complications in a tertiary care hospital [Internet]. Vol. 11, Journal of Laboratory Physicians. 2019. p. 265-9.

40. Kort R. XVII International AIDS Conference: From Evidence to Action - AIDS 2008 and the global response to AIDS [Internet]. Vol. 12, Journal of the International AIDS Society. 2009. p. S7.

41. Sekar D, Lakshmanan G, Mani P, Biruntha M. Methylationdependent circulating microRNA 510 in preeclampsia patients. Hypertens Res. 2019 May 21;42(10):1647-8.

42. Johnson J, Lakshmanan G, M B, R M V, Kalimuthu K, Sekar D. Computational identification of MiRNA-7110 from pulmonary arterial hypertension (PAH) ESTs: a new microRNA that links diabetes and PAH. Hypertens Res. 2020 Apr;43(4):360-2.

43. Muthamizharasi R, Sri Sairam Siddha Medical College and Research Centre, Tambaram W, Chennai., Subhashini R, Sathish $\mathrm{R}$, et al. Under Graduates Attitude Towards Siddha System Of Medicine - A Questionnaire Based Study [Internet]. Vol. 3, International Journal of Advanced Research in Biological Sciences (IJARBS). 2016. p. 241-6.

44. Harborne JB. Indian Medicinal Plants. A Compendium of 500 Species. Vol.1; Edited by P. K. Warrier, V. P. K. Nambiar and C. Ramankutty [Internet]. Vol. 46, Journal of Pharmacy and Pharmacology. 1994. p. 935-935.

45. Bhavani S. A Review on Anti-Helminthic Herbs in Siddha [Internet]. Vol. 6, International Research Journal of Pharmacy. 2015. p. 689-92.

46. Kiran G, Karthik L, Shree Devi MS, Sathiyarajeswaran P, Kanakavalli K, Kumar KM, et al. In Silico computational screening of Kabasura Kudineer - Official Siddha Formulation and JACOM against SARS-CoV-2 spike protein. J Ayurveda Integr Med [Internet]. 2020 May 25 